DOI: $10.6060 / \mathrm{mhc} 161284 \mathrm{i}$

\title{
Tetraphenylporphyrinylmethyltriphenylphosphonium Salts: an Improved Synthetic Protocol
}

\author{
Vladimir V. Berezovskii, Yuriy V. Ishkov, ${ }^{\circledR}$ and Sergey V. Vodzinskii \\ I.I. Mechnikov Odessa National University, 65026 Odessa, Ukraine \\ ${ }^{\circledR}$ Corresponding authorE-mail: jvi@eurocom.od.ua
}

Triphenyl[ $(5,10,15,20$-tetraphenylporphyrin-2-yl)methyl]phosphonium chloride, bromide, and trifluoroacetate were obtained by reacting 2-hydroxymethyl-5,10,15,20-tetraphenylporphyrin with, respectively, hydrogen chloride and triphenylphosphine, triphenylphosphonium hydrobromide, or a mixture of triphenylphosphine, trifluoroacetic acid and trifluoroacetic anhydride. All the salts afforded high yields in a model Wittig reaction with terephthalic aldehyde.

Keywords: Porphyrin, phosphonium salt, chloride, bromide, trifluoroacetate, alkene, Wittig reaction.

\section{Улучшенный метод синтеза тетрафенилпорфиринилметилфосфониевых солей}

\author{
В. В. Березовский, Ю. В. Ишков, ${ }^{\circledR}$ С. В. Водзинский \\ Одесский национальный университет им. И.И. Мечникова, 65026 Одесса, Украина \\ ${ }^{\circledR}$ E-mail: jvi@eurocom.od.ua
}

\begin{abstract}
Хлорид, бромид и трифторачетат трифенил[(5,10,15,20-тетрафенилпорфирин-2-ил)метил]фосфония были получены, исходя из 2-гидроксиметил-5,10,15,20-тетрафенилпорфирина. Все эти соли дали высокие выходы иелевого продукта в модельной реакиии Виттига с терефталевым альдегидом.
\end{abstract}

Ключевые слова: Порфирин, соль фосфония, хлорид, бромид, трифторацетат, алкен, реакция Виттига.

The Wittig olefin synthesis has found broad application in the chemistry of porphyrins. Since 1988, phosphonium ylides prepared from porphyrinylmethylphosphonium salts are used to create exocyclic double bonds in porphyrins. ${ }^{[1]}$ In order to extend our research in the field of vinylporphyrinic monomers, ${ }^{[2,3]}$ a convenient and scalable synthetic procedure for phosphonium salts, containing triphenyl[(5,10,15,20tetraphenylporphyrin-2-yl)methyl]phosphonium cation, was required.

Earlier we have demonstrated, ${ }^{[3]}$ that Officer's procedure, ${ }^{[4,6]}$ for the synthesis of triphenyl $[(5,10,15,20$-tetraphenylporphyrin-2-yl)methyl]phosphonium chloride (I), cannot be reproduced even for the step of synthesis of its precursor - 2-chloromethyl-5,10,15,20-tetraphenylporphyrin (II). We decided to test the "one-pot" approach to obtain (I) - 2-hydroxymethyl-5,10,15,20-tetraphenylporphyrin was converted to the corresponding chloromethylporphyrin (II) by a mixture of triphenylphosphine and carbon tetrachlo- ride (Appel reaction), the volatile components were distilled off and the reaction mixture containing porphyrin (II) was treated with a fresh triphenylphosphine solution, affording salt (I). The best results were achieved when acetonitrile was used as the solvent, however the isolation of product (I) was quite tedious as large excesses of the reactants were required, resulting in the formation of side products in significant amounts. The synthesis was also time-consuming and hard to scale-up.

The amount of side products was reduced by performing the reaction of hydroxymethylporphyrin (III) with gaseous $\mathrm{HCl}$ in refluxing chloroform or methylene chloride followed by distillation of the solvent in a stream of $\mathrm{HCl}$. In order to complete the reaction, the procedure had to be repeated twice. The reaction rate in chloroform was significantly higher than in methylene chloride. The formed chloromethylporphyrin (II) was not isolated in a pure form and was treated with triphenylphosphine in refluxing 


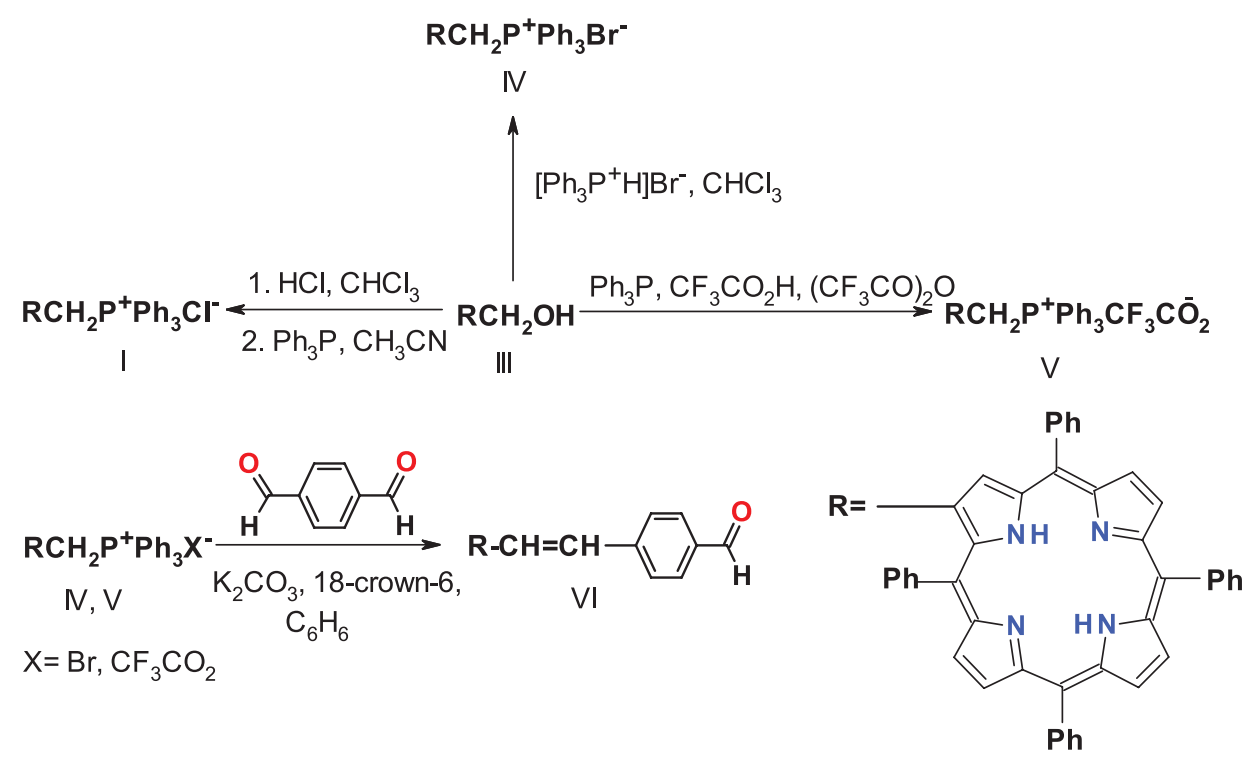

chloroform or acetonitrile. As described in, ${ }^{[3]}$ the formation of phosphonium salt (I) was very slow in chloroform, while using acetonitrile allowed to complete the reaction in $30 \mathrm{~h}$ with a $76 \%$ overall yield. In comparison to work $^{[3]}$ the isolation and purification work-up for phosphonium salt (I) was simplified considerably. Furthermore, the spent quantity of triphenylphosphine was reduced twice. However, some issues may be caused by the use of gaseous $\mathrm{HCl}$ and the reaction time increased by $6-7 \mathrm{~h}$.

Literature analysis reveals many procedures for direct transformation of hydroxymethyl derivatives into triphenylmethylphosphonium salts, which are performed without the isolation of the intermediate methyl halide. However, none of these procedures was used for the synthesis of porphyrinylmethyltriphenylphosphonium salts. Among the mentioned procedures is the reaction of primary alcohols with triphenylphosphonium hydrobromide ${ }^{[7]}$ or a mixture of triphenylphosphine and trifluoroacetic acid. ${ }^{[8]}$

As the reaction of hydroxymethylporphyrin (III) with 1.1-2.0 eq. of both reactants proceeded very slowly, we used them in 10-fold excess, which allowed to reduce the time required to obtain triphenyl[(5,10,15,20-tetraphenylporphyrin-2-yl)methyl]phosphonium bromide (IV) and triphenyl$[(5,10,15,20$-tetraphenylporphyrin-2-yl)methyl $]$ phosphonium trifluoroacetate $(\mathbf{V})$.

Acetonitrile, dichloromethane and chloroform were used as solvents for the reaction of hydroxymethylporphyrin (III) with triphenylphosphonium bromide. The best results were achieved in chloroform $-87 \%$ yield of salt (IV) after a $21 \mathrm{~h}$ reaction time. However, we consider the optimal procedure for the synthesis of porphyrinylmethylphosphonium building block to be the one for trifluoroacetate $(\mathbf{V})$. The yield was $87 \%$ after an $18 \mathrm{~h}$ reaction time. The addition of 2 eq. of trifluoroacetic anhydride to the reaction mixture followed by $1 \mathrm{~h}$ stirring at ambient temperature and $17 \mathrm{~h}$ refluxing resulted in an improved yield ( $92 \%$ ).

As expected, using triphenylporphyrinylmethylphosphonium bromide (IV) or trifluoroacetate (V) instead of the corresponding chloride (I) in a model Wittig reaction with terephthalic aldehyde under conditions similar to $^{[3]}$ did not have a considerable effect on the reaction time and yield of 2-[2-(4-formylphenyl)ethene-1-yl]-5,10,15,20tetraphenylporphyrin (VI).

In conclusion, a convenient, reproducible, and easily scalable procedures for the synthesis of valuable porphyrincontaining Wittig reagents were proposed. This allows for extended diversity of synthetic porphyrins.

\section{Experimental}

The ${ }^{1} \mathrm{H}$ NMR spectra were recorded in $\mathrm{CDCl}_{3}$ on a Brucker DPX-300 spectrometer operating at $300.13 \mathrm{MHz}$, using TMS as the internal standard. The FAB mass spectra were recorded on a VC 7070 EQ instrument. Ion desorption was performed by a $8 \mathrm{keV}$ xenon particle beam from a 3-nitrobenzyl alcohol matrix. The exact molecular ion masses were determined at the instrument resolution of 10000 . The electronic absorption spectra were recorded on a Specord M-40 spectrophotometer in $\mathrm{CHCl}_{3}$ $\left(C=10^{-5} \mathrm{~mol} \cdot \mathrm{L}^{-1}\right)$. Thin layer chromatography was performed on Silufol plates. Column chromatography was conducted on silica gel 60 type $9385(40-63 \mu \mathrm{m})$ from Merck. 2-Hydroxymethyl$5,10,15,20$-tetraphenylporphyrin was synthesized according to the literature. ${ }^{[4]}$

Triphenyl[(5,10,15,20-tetraphenylporphyrin-2-yl)methyl] phosphonium chloride (I). A stream of dry $\mathrm{HCl}$ was passed for $5 \mathrm{~h}$ through a refluxing solution of $0.562 \mathrm{~g}\left(8.72 \cdot 10^{-4} \mathrm{~mol}\right)$ of hydroxymethylporphyrin (III) in $125 \mathrm{~mL}$ of chloroform. The solvent was then distilled off while the stream of $\mathrm{HCl}$ still on. The procedure was repeated twice using 100 and $75 \mathrm{~mL}$ of chloroform. Then $2.287 \mathrm{~g}\left(8.72 \cdot 10^{-3} \mathrm{~mol}\right)$ of triphenylphosphine in $100 \mathrm{~mL}$ of acetonitrile was added to the dry residue and the mixture was refluxed for $30 \mathrm{~h}$. The solvent was evaporated, the residue was dissolved in $270 \mathrm{~mL}$ of chloroform, washed with water, cold $0.5 \%$ sodium hydrocarbonate solution, again water, the organic layer was collected, the solvent was evaporated. The residue was dissolved in chloroform $(100 \mathrm{~mL})$ and applied onto column with silica $(2.5 \times 10 \mathrm{~cm})$. The column was eluted with chloroform followed by a chloroform-methanol mixture (10:1). The major band containing the phosphonium salt (I) was collected, the eluent was evaporated and the residue was crystallized from a mixture of chloroformethyl acetate (1:3). Yield $0.613 \mathrm{~g}(76 \%) . m / z(\%) 889[\mathrm{M}-\mathrm{Cl}]^{+}(100)$, 890 (45), 891 (18), $627\left[\mathrm{M}-\mathrm{CPh}_{3} \mathrm{Cl}\right]^{+}$(72). UV-Vis $\lambda_{\text {max }}(\lg \varepsilon) \mathrm{nm}:$ 
425 (5.14), 522 (4.12), 551 (3.96), 598 (3.86), 655 (3.54). ${ }^{1} \mathrm{H}$ NMR $\delta_{\mathrm{H}}$ ppm: $8.85 \mathrm{~d}, 8.78 \mathrm{~m}, 8.45 \mathrm{~d}, 8.28 \mathrm{~d}(7 \mathrm{H}, \beta$-pyrrole), $8.16 \mathrm{~d}(4 \mathrm{H}$, $o$-phenyl), 7.50-7.85 m (17H, $m$-, $p$-, $o$-phenyl, $p$-phenyl.phosph.), $7.40 \mathrm{~d}(2 \mathrm{H}, o$-phenyl), $7.27 \mathrm{~m}(6 \mathrm{H}, m$-phenyl.phosph.), $7.10 \mathrm{~d}(6 \mathrm{H}$, $o$-phenyl.phosph.), $5.13 \mathrm{~d}\left(2 \mathrm{H},-\mathrm{CH}_{2}-\right),-2.75$ wid. s. $(2 \mathrm{H}, \mathrm{NH})$.

Triphenyl $[(5,10,15,20$-tetraphenylporphyrin-2-yl)methyl]phosphonium bromide $(\boldsymbol{I V})$. A mixture of $0.412 \mathrm{~g}\left(6.39 \cdot 10^{-4} \mathrm{~mol}\right)$ of hydroxymethylporphyrin (III), $2.193 \mathrm{~g}\left(6.39 \cdot 10^{-3} \mathrm{~mol}\right)$ triphenylphosphine hydrobromide ${ }^{[5]}$ and $120 \mathrm{~mL}$ of chloroform was refluxed for $20 \mathrm{~h}$, then the solvent was slowly distilled off during $1 \mathrm{~h}$. The residue was dissolved in $200 \mathrm{~mL}$ of chloroform, washed with water, cold $1 \%$ sodium hydrocarbonate solution, again water, the organic layer was collected, the solvent was evaporated. The crude product was dissolved in $75 \mathrm{~mL}$ of chloroform and applied onto a silica column $(2.5 \times 8 \mathrm{~cm})$. The major porphyrinic band was collected, the eluent was evaporated and the residue was crystallized from a mixture of chloroform-ethyl acetate (1:3). Yield $0.533 \mathrm{~g}(86 \%) . m / z(\%) 889[\mathrm{M}-\mathrm{Br}]^{+}$(100), 890 (40), 891 (22), 627 $\left[\mathrm{M}-\mathrm{CPh}_{3} \mathrm{Br}\right]^{+}(69)$. UV-Vis $\lambda_{\max }(\lg \varepsilon) \mathrm{nm}: 424$ (5.07), 521 (4.06), 552 (3.88), 596 (3.80), 653 (3.49)

Triphenyl $[(5,10,15,20$-tetraphenylporphyrin-2-yl)methyl] phosphonium trifluoroacetate $(\boldsymbol{V}) .0 .3 \mathrm{~mL}\left(2.1 \cdot 10^{-3} \mathrm{~mol}\right)$ of trifluoroacetic anhydride was added to a mixture of $0.664 \mathrm{~g}\left(1.03 \cdot 10^{-3}\right.$ mol) hydroxymethylporphyrin (III), $2.702 \mathrm{~g}\left(1.03 \cdot 10^{-2} \mathrm{~mol}\right)$ of triphenylphosphine, $25 \mathrm{~mL}$ of trifluoroacetic acid. The mixture was stirred at ambient temperature for $1 \mathrm{~h}$, then it was refluxed for $17 \mathrm{~h}$, the solvent was evaporated, the residue was dissolved in $320 \mathrm{~mL}$ of chloroform, washed with water, cold $0.5 \%$ sodium hydrocarbonate solution, again with water, then organic layer was collected, the solvent was evaporated. The residue was dissolved in $120 \mathrm{~mL}$ of chloroform and applied onto silica column $(2.5 \times 9 \mathrm{~cm})$. The column was eluted with chloroform followed by a chloroform-methanol 10:1 mixture. The major porphyrinic band was collected, the solvent was evaporated and the residue was crystallized from a chloroform-ethyl acetate mixture (1:3). Yield $0.950 \mathrm{~g}(92 \%) . \mathrm{m} / z 889\left[\mathrm{M}-\mathrm{CF}_{3} \mathrm{CO}_{2}\right]^{+}$(100), 890 (46), 891 (25), $627\left[\mathrm{M}-\mathrm{CPh}_{3} \mathrm{CF}_{3} \mathrm{CO}_{2}\right]^{+},(75)$. UV-Vis $\lambda_{\text {max }}$ (lge) nm: 424 (5.16), 522 (4.16), 550 (4.01), 598 (3.88), 654 (3.58).

2-[2-(4-Formylphenyl)ethene-1-yl]-5,10,15,20-tetraphenylporphyrin (VI). A mixture of $0.151 \mathrm{~g}(0.163 \mathrm{mmol})$ of porphyrinylmethylphosphonium chloride (I) [or $0.158 \mathrm{~g}(0.163 \mathrm{mmol})$ of porphyrinylmethylphosphonium bromide (IV), or $0.164 \mathrm{~g}(0.163 \mathrm{mmol})$ of porphyrinylmethylphosphonium trifluoroacetate $(\mathbf{V})], 0.066 \mathrm{~g}$ ( $0.489 \mathrm{mmol})$ of terephthalic aldehyde, $0.225 \mathrm{~g}(1.63 \mathrm{mmol})$ of potassium carbonate, $0.008 \mathrm{~g}(0.03 \mathrm{mmol})$ of 18 -crown- 6 in $30 \mathrm{~mL}$ of benzene was refluxed for $11 \mathrm{~h}$. The mixture was then cooled, filtered through a plug of alumina $(3 \times 5 \mathrm{~cm})$, evaporated to a volume of $7 \mathrm{~mL}$ and diluted with $14 \mathrm{~mL}$ of methanol. The obtained suspension was warmed to $50{ }^{\circ} \mathrm{C}$, then a solution of $0.05 \mathrm{~g}$ ammonium chloride in $9 \mathrm{~mL}$ of water with a temperature of $50{ }^{\circ} \mathrm{C}$ was introduced. The mixture was stirred, maintaining the temperature, for $30 \mathrm{~min}$, then cooled and the precipitate was filtered. The precipitate was then washed with $10 \mathrm{~mL}$ of $50 \%$ aqueous ethanol, $30 \mathrm{~mL}$ of water at $50{ }^{\circ} \mathrm{C}$ and dried for $5 \mathrm{~h}$ at $110{ }^{\circ} \mathrm{C}$, redissolved in a minimum of a benzene-carbon tetrachloride mixture and subjected to chromatography on silica $(2.5 \times 30 \mathrm{~cm})$. The eluent was a 1:1 mixture of benzene-carbon tetrachloride. The product was crystallized from a chloroform-methanol mixture (1:2). Yield $0.104 \mathrm{~g}(86 \%)$, [0.103 g (85\%) from bromide (IV), $0.104 \mathrm{~g} \mathrm{(86 \% )}$ from trifluoroacetate $(\mathbf{V})], \mathrm{R}_{f} 0.27$ (benzene). $\mathrm{m} / \mathrm{z}(\%) 744[\mathrm{M}]^{+}$ (100). UV-Vis $\lambda_{\max }$ (lge) nm: 428 (5.35), 525 (4.24), 565 (4.05), 601 (3.85), 657 (3.62). ${ }^{1} \mathrm{H}$ NMR $\delta_{\mathrm{H}}$ ppm: $10.02 \mathrm{~s}(1 \mathrm{H}, \mathrm{CHO}), 9.04$ $\mathrm{s}(1 \mathrm{H}, \beta$-pyrrole), 8.85-8.71 m (6H, $\beta$-pyrrole), 8.28-8.17 m $(6 \mathrm{H}$, $o$-phenyl), 7.85-7.70 m (14H, $m$-, $p$-phenyl, $o$-, $m$-phenylene), 7.39 $\mathrm{d}(2 \mathrm{H}, o-, m$-phenylene), $7.33 \mathrm{~d}(1 \mathrm{H}, J=16.1 \mathrm{~Hz}$, ethylene), $7.15 \mathrm{~d}$ $(1 \mathrm{H}, J=16.1 \mathrm{~Hz}$, ethylene), -2.59 wid. s. $(2 \mathrm{H}, \mathrm{NH})$.

Acknowledgements. The authors would like to thank Ph.D. A. V. Mazepa for the help in recording and interpreting mass spectral data.

\section{References}

1. Burrell A.K., Officer D.L. Synlett 1998, 12, 1297-1307.

2. Berezovskii V.V., Ishkov Yu.V., Mazepa A.V. Russ. J. Org. Chem. 2010, 46, 1409-1413.

3. Berezovskii V.V., Ishkov Yu.V., Mazepa A.V. Macroheterocycles 2013, 6, 251-256.

4. Bonfantini E.E., Burrell A.K., Campbell W.M., Crossley M.J., Gosper J.J., Harding M.M., Officer D.L., Reid D.C.W. J. Porphyrins Phthalocyanines 2002, 6, 708-719.

5. Hercouet A., Le Corre M. Synthesis 1988, 157-158.

6. Bonfantini E.E., Officer D.L. Tetrahedron Lett. 1993, 34, 8531-8534.

7. Zang J-X., Dubois Ph., Jerome R. Synth. Commun. 1996, 26, 3091-3095.

8. Lee K.Y., Kim J.N. Bull. Korean. Chem. Soc. 2000, 21(8), 763-764. 